\title{
THE MODERN APPROACHES TO THE CREATION OF PEDAGOGICAL CONDITIONS OF PRIMARY SCHOOL TEACHER'S PROFESSIONAL ADAPTATION DURING PEDAGOGICAL PRACTICE
}

\author{
Oksana Zamiatna \\ Head of the Department of Students Practice and Employment of the Scientific \\ and Methodological Center for Standardization and Quality of Education, \\ Borys Grinchenko Kyiv University, Ukraine \\ e-mail: o.zamiatna@kubg.edu.ua,orcid.org/0000-0002-0707-1501
}

\section{Summary}

The article is devoted to the problem of professional adaptation of the future primary school teacher, the solution of which is aimed at increasing their competitiveness. Based on the analysis of scientific works, it is established that the process of professional adaptation begins during professional training. As this process is dynamic and pedagogically controlled, it requires the creation of special pedagogical conditions that will take into account modern approaches to the organization of the educational process.

It is proposed to carry out systematic monitoring of professional adaptation of students in the process of pedagogical practice to diagnose the formation of their professional adaptation and the relevant criteria are set. In order to determine areas for improving the content of pedagogical practice, the current state of normative support of students' practice in Ukraine at the national level and at the level of higher education institutions (on the example of Borys Grinchenko Kyiv University) is analyzed. Purposeful management of the process of professional adaptation of the future primary school teacher is realized through the support of future primary school teachers during pedagogical practice. The article describes the forms, content and tasks to which its implementation is aimed.

Keywords: adaptation to the professional environment, content of practice, methodological support, monitoring of professional adaptation, practical training, pedagogical conditions, primary school teacher, support of practice.

\section{DOI https://doi.org/10.23856/4111}

\section{Introduction}

The current socio-economic changes in Ukraine and the strategic challenges facing higher education in Ukraine have necessitated the solution of the problem of training competitive professionals who are able to quickly adapt to the conditions of professional activity. Although in recent years this problem has been actively studied by scientists in various scientific fields and directions, the question of professional adaptation of future primary school teachers remains open.

As the professional adaptation of the future primary school teacher we understand the process of adaptation to the professional environment of the educational institution, professional activity, its conditions and requirements of the professional standard. The primary education system in Ukraine is currently in a state of transformation due to the implementation of the state concept which is called «The New Ukrainian School» (2016). At the same time, according to the Professional standard (2018) the work of primary school teachers involves "a high level of psychophysiological and emotional load, responsibility for the formation of the educational 
environment and compliance with measures and rules for student safety", which complicates the process of professional adaptation.

The purpose of the study is to determine modern approaches to creating special pedagogical conditions in the process of pedagogical practice by future primary school teachers aimed at their adaptation to the future profession. Since the process of professional adaptation actually begins during vocational training, by introducing such conditions into the system of practical training, we see the possibility of solving the problem of professional adaptation of the future specialist of primary school.

\section{Monitoring of professional adaptation in the process of pedagogical practice}

A feature of the process of professional adaptation of the future primary school teacher in the process of pedagogical practice is its dynamism. Therefore, systematic monitoring of professional adaptation during pedagogical practice is considered as one of the important pedagogical conditions of professional adaptation of the future primary school teacher, which will provide an opportunity to manage and timely adjust this process.

The notion "monitoring" means the constant observation of any process in order to determine its compliance with the desired result (Elnikova, 2011: 10). We agree with the understanding of monitoring as "a specially organized regular observation of a process using a relatively stable limited number of standardized indicators that reflect the priority causal relationship between people and their relationships and making forecasts, corrective actions" (Shevchenko, 2013: 229).

To summarize the results of scientific work on the research problem, monitoring the professional adaptation of future primary school teachers during pedagogical practice is considered as a system of observation, collection, processing and analysis of information about the state and level of professional adaptation of students, forecasting their changes and developing scientifically sound recommendations for management solutions to improve and correct the process of professional adaptation.

Among the tools for monitoring of professional adaptation in the process of pedagogical practice are: questionnaires and surveys, various forms of observation and introspection, student's performing of competence tasks during the teaching practice.

The components of professional adaptation of the future primary school teacher are motivational-value, cognitive, activity-procesual and emotional-reflexive components. The criteria for diagnosing of formation of the future primary school teacher' professional adaptation are: his awareness and perception of the system of humanistic values in the educational process of primary school and the presence of positive social values in pedagogical interaction (the motivational-value component); the quality of knowledge, their understanding and confidence, purposefulness, variality (the cognitive component); formation of professional pedagogical skills and abilities (the activity-procesual component); satisfaction with their own pedagogical activities, orientation in their own capabilities and abilities, awareness of the importance of self-esteem and self-control (the emotional-reflexive component).

The presence of such phenomena as difficulties and barriers in the future teacher reduces the success of professional adaptation and its effectiveness. Therefore, the object of monitoring of students' professional adaptation is the manifestation of psychological and pedagogical difficulties and barriers in the process of pedagogical practice, which may arise in the future primary school teacher and lead to anxiety and low self-esteem, interfere with the implementation of acquired knowledge. Monitoring of professional adaptation makes it possible to identify the root cause of such phenomena as difficulties and barriers of the future 
primary school teacher during pedagogical practice and to overcome such obstacles. This, in turn, helps students to master the necessary practical skills and abilities.

\section{Regulatory and methodological support of pedagogical practice in Ukraine}

Regulatory support for the practical training of future primary school teachers includes:

- Normative documents of the Ministry of Education and Science of Ukraine on the practice of future specialists (Regulations on the practice of students of higher educational institutions of Ukraine, professional standard "Primary school teacher of general secondary education", the Concept "New Ukrainian school");

- Normative documents of higher education institution on the practical training for specialty 013 "Primary Education" (Regulations on students' practice, Educational Program Profile 013.00.01 «Primary Education», programs on each type of practice, guidelines for practice).

Although issues related to the organization, provision, conduct and content of practice have been long in the center of attention of many scholars, regulatory support of practical training in Ukraine at the national level has remained unchanged since 1994 (Regulations on the practice of students of higher educational establishments of Ukraine).

On the example of Borys Grinchenko Kyiv University, where the New Education Strategy has been introduced since 2017, we can consider the current conditions of professional adaptation of the future specialist in the process of practical training.

The new educational strategy of the University provides for the training of students in practical centers - Centers of Competence in order to improve the competitiveness of graduates. A new strategy for training of future professionals is training based on practical activities and research. Its feature is also a reduction in time for theoretical training in traditional lectures and seminars, as well as the transition to practice-oriented training - by increasing the hours for practical training.

An analysis of various curricula for training specialists in the specialty 013 «Primary Education» for the first (bachelor's) level of higher education at the Borys Grinchenko Kyiv University in terms of the amount of hours devoted to practice, of the total number of hours found that:

- for the curriculum of 2015 year $-17.5 \%$,

- for the curriculum of 2017 year $-24,3 \%$,

- for the curriculum of 2018 year $-26,3 \%$.

Thus, under the current curriculum Bachelor specialty «Primary education» was an increasing of the share of practical training of future professionals. According to it, each training course provides for various types of practice, namely: educational (psychological-pedagogical) practice in the second semester (3 credits); educational (propaedeutic) practice in III, IV, V semesters ( 9 credits); production (educational-methodical) practice in VI, VII, VIII semesters (51 credits).

Methodological support involves the development of a program for each type of practice for students specialty 013 «Primary Education», as well as guidelines for their origin. The labor functions and competencies that a teacher must master in accordance with the Professional Standard «Primary School Teacher of General Secondary Education» (2018) must be taken into account and be a meaningful component of the professional adaptation of future primary school teachers during the pedagogical practice.

\section{Directions for improving the content of pedagogical practice}

There is a general methodological position, according to which pedagogical practice should contribute to the formation of professional competence in a real professional environment, as well as professional adaptation to such an environment, within our research. 
During the improvement of the content-methodical component of pedagogical practice we took as a basis the developed and substantiated principles of selection of the content of practice of future primary school teachers in the conditions of gradual training (Kazakova, 2005; Martynenko, 2009): taking into account the needs of modern educational space and the region; specifics of formation of professional competence of the future primary school teacher; direction of pedagogical practice on personal and professional development of students; variation of the content, forms and methods of pedagogical practice; continuity of this process; research oriented of pedagogical practice; combination of pedagogical practice with the implementation of course (diploma) work (project) of students; coordination of efforts of subjects of management and self-management of pedagogical practice.

The activity of students in the Centers of Competence, which are structural units of the University, is the first link in the structural-logical scheme of training a modern specialist, aimed at his professional adaptation: «Audience - Centers of Competence - Base of Practice Place of work.» Among the main areas of work of such units are the preparation of students for pedagogical practice and increase the level of formation of their professional competencies.

The step-by-step model of future primary school teachers' practice under the new education strategy is built in such a way that at the initial stage students have the opportunity to gradually «enter the profession», starting with their involvement in a quasi-professional environment, which it is a network of Competence Centers. And at the final stage of the bachelor's degree to immerse oneself in the real professional environment as much as possible in the process of passing pedagogical practice in general secondary education institutions of different types and forms of ownership (privat and government).

According to the current Law of Ukraine «On Higher Education» (2014), employers can be involved in the educational process of higher education and participate directly in the training of future teachers, including in the development of methodological support for the educational process. Such obligations of employers are real to fulfill, as general secondary education institutions themselves are interested in quality training of future teachers who will continue to work there. With such close cooperation between the school and the university, built on mutually beneficial partnership principles, it will be possible to avoid differences between theoretical teaching and the professional knowledge, skills and abilities that a modern primary school requires from a teacher.

\section{Support of students in the process of pedagogical practice}

The analysis of psychological, pedagogical and methodological literature allowed to establish that the concept of «professional adaptation of the future primary school teacher» is multifaceted, and the process of professional adaptation is pedagogically controlled and dynamic. The activity of the future primary school teacher during the pedagogical practice is supervised by the teacher-supervisor of the practice and the teacher-mentor appointed by the base of practice, when the student performs the system of tasks defined in the practice program.

As the psychological and pedagogical support of professional adaptation of the future primary school teacher in the process of practice we understand the purposeful process of analysis, development and correction of pedagogical activity of the student at the stage of his entry into the professional environment. The implementation of psychological and pedagogical support for future primary school teachers during pedagogical practice involves individual and group mentoring. This is done by assigning to each student a supervisor who is an experienced professional in the field and will be able to provide qualified student assistance.

The implementation of psychological and pedagogical support of students - future primary school teachers - during pedagogical practice is aimed at performing the following tasks: identification of professional qualities of students in the process of performing practice 
tasks; creating a favorable educational environment; prevention of problematic situations and difficulties for students; promoting the establishment of interpersonal relationships of the student with pupils, teachers, parents of pupils, the administration of the practice base, the teaching staff as a whole and other students; increasing a students' motivation to take pedagogical practice.

During the pedagogical practice, each student is assigned a supervisor from the university, who primarily provides psychological and pedagogical support. At the same time, arriving at the base of practice, the student is also assigned a supervisor from this institution, who actually becomes his mentor on the practice. Thus, an important component of pedagogical support of professional adaptation of the future teacher, which is carried out by the mentor from the base of practice is the creation of an effective professional adaptive environment.

The content of psychological and pedagogical support of professional adaptation of students during pedagogical practice should be realized in:

- assessing the real level of his professional adaptability;

- providing assistance in improving the professional skills of students; school teachers;

- promoting the development of internal professional motivation of future primary

- prevention of difficulties and crises arising from the mismatch of professional expectations and the professional reality in the process of pedagogical practice, assistance to overcome it;

- prevention of professional burnout, etc.

Adaptive support during psychological and pedagogical support of practice is divided into the following stages: 1) diagnostics (the problem is defined); 2) searching (there is a joint search for causes and solutions, discussing possible consequences); 3) projecting (there is separation of functions for the solution of the problem, outlines ways of interaction); 4) activity (the student acts, and the supervisor approves, protects and corrects his actions); 5) reflexive (earlier stages of activity are discussed, it is found out, how much the problem is solved) (Luchentsova, 2015: 156).

The activities of the appointed supervisor of the practice should be aimed at promoting the professional adaptation of students and include psychological and pedagogical support in the process of pedagogical practice, taking into account the content and methodological component of practice, monitoring the future teacher's professional adaptation and diagnosing its effectiveness (see Fig. 1).

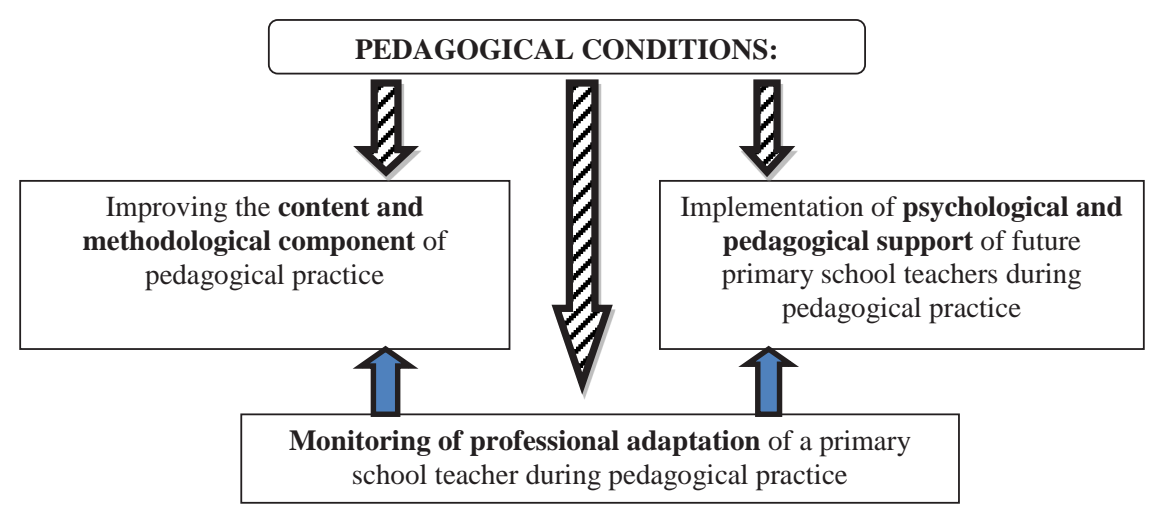

\section{Fig. 1. Pedagogical conditions of professional adaptation of the future primary school teacher in the process of pedagogical practice}




\section{Conclusions}

Thus, the competence approach to the organization of pedagogical practice of future primary school teachers will provide an opportunity to create such conditions in which they will feel more confident in their own professional activities. We believe that the creation in the process of pedagogical practice of future primary school teachers such pedagogical conditions as: implementation of psychological and pedagogical support of students during pedagogical practice, improvement of the content and methodological component of pedagogical practice and systematic monitoring of professional adaptation of the future specialist in the process of pedagogical practice, - will promote their adaptability to the professional environment and the requirements of the Professional standard.

The prospect of further research of the outlined problem is the development of methodological support for pedagogical practice that takes into account the developed pedagogical conditions.

\section{References}

Elnikova G. (2011) Tekhnolohiia adaptyvnoho Upravlinnia personalom orhanizatsii [Technology of adaptive personnel management of the organization] Naukovyi visnyk Instytutu profesiino-tekhnichnoi osvity NAPN Ukrainy. Ser. : Profesiina pedahohika - Scientific Bulletin of the Institute of Vocational Education of the National Academy of Pedagogical Sciences of Ukraine. : Professional pedagogy, 1, 8-14. Retrieved from http://nbuv.gov.ua/UJRN/ Nvipto_2011_1_4 [in Ukrainian].

Kazakova N. (2005) Orhanizatsiino-metodychni zasady pedahohichnoi praktyky maibutnikh uchyteliv pochatkovoi shkoly $v$ umovakh stupenevoi pidhotovky [Organizational and methodological principles of pedagogical practice of future primary school teachers in terms of degree training] Extended abstract of candidate's thesis. Kyiv [in Ukrainian].

Luchentsova I. (2015) Adaptatsiia do profesiinoi diialnosti studentiv pedahohichnoho koledzhu $v$ protsesi pedahohichnykh praktyk [Adaptation to the professional activity of students of pedagogical college in the process of pedagogical practices]. Candidate's thesis. Kharkiv [in Ukrainian].

Martynenko S. (2009) Systema pidhotovky vchytelia pochatkovykh klasiv do diahnostychnoi diialnosti [The system of preparation of primary school teachers for diagnostic activities]. Doctor's thesis. Kyiv [in Ukrainian].

Pro skhvalennia Kontseptsii realizatsii derzhavnoi polityky u sferi reformuvannia zahalnoi serednoi osvity "Nova ukrainska shkola" na period do 2029 roku: Rozporiadzhennia Kabinetu Ministriv Ukrainy vid 14.12.2016 № 988-r. [About approval of the Concept of realization of the state policy in the field of reforming of general secondary education "New Ukrainian school» for the period till 2029: Order of the Cabinet of Ministers of Ukraine from 14.12.2016 № 988-r]. zakon.rada.gov.ua. Retrieved from https://zakon.rada.gov.ua/laws/show/988-2016$\%$ D1\%80?lang=en\#Text [in Ukrainian].

Pro vyshchu osvitu: Zakon Ukrainy vid 01.07.2014 № 1556-VII [Law of Ukraine On Higher Education from 01.07.2014 № 1556-VII]. zakon.rada.gov.ua. Retrieved from https://zakon. rada.gov.ua/laws/show/1556-18 [in Ukrainian].

Pro zatverdzhennia Polozhennia pro provedennia praktyky studentiv vyshchykh navchalnykh zakladiv Ukrainy : Nakaz ministerstva osvity Ukrainy vid 08.04.1993 r. № 93 [On approval of the Regulations on the practice of students of higher educational institutions of Ukraine: Order 
of the Ministry of Education of Ukraine from 08.04.1993 № 93] zakon.rada.gov.ua. Retrieved from https://zakon.rada.gov.ua/laws/show/z0035-93\#Text [in Ukrainian].

Pro zatverdzhennia profesiinoho standartu «Vchytel pochatkovykh klasiv zakladu zahalnoi serednoi osvity»: nakaz Ministerstva sotsialnoi polityky Ukrainy vid 10.08.2018 № 1143 [On approval of the professional standard «Primary school teacher of general secondary education»: Order of the Ministry of Social Policy of Ukraine from 10.08.2018 № 1143]. zakon. rada.gov.ua. Retrieved from https://zakon.rada.gov.ua/rada/show/v1143732-18?lang=uk\#Text [in Ukrainian].

Shevchenko S. (2013) Sutnist, spetsyfika y osoblyvosti monitorynhu yak dzherelnoho bazysu dlia otsiniuvannia yakosti vyshchoi osvity [The essence, specifics and features of monitoring as source base for assessing the quality of higher education] Udoskonalennia systemy monitorynhu zabezpechennia yakosti vyshchoi osvity Ukrainy - Improving the quality assurance monitoring system of higher education in Ukraine: Proceedings of the Scientific-Practical conference "Personnel support of mining and metallurgical of the complex of Ukraine», pp. 228-234. Dnipropetrovsk: DVNZ «NHU» [in Ukrainian]. 